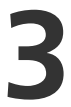

\title{
Cooking Commoning Subjectivities: Guerrilla Narrative in the Cooperation Birmingham Solidarity Kitchen
}

\author{
Sergio Ruiz Cayuela and Marco Armiero
}

\section{Introduction}

Capitalism is a system inherently unequal and undemocratic (Wood, 1995). In the capitalist social and productive organization, a small elite is constantly accumulating wealth by dispossessing the rest of the population of their labour (waged or unwaged) and transforming people and the environment either into resources to be exploited or socio-ecological dumps for the toxic remains of production and consumption. These facts, which remain hidden in plain sight for most of us, lead to an uncontestable conclusion: capitalism is not sustainable and very few people benefit from it. Why then would the majority of the population accept their subaltern position with all its consequences (dispossession

\footnotetext{
S. Ruiz Cayuela ( $\otimes)$

Rachel Carson Center, Munich, Germany

M. Armiero

Institute for Studies on the Mediterranean, CNR, Rome, Italy

Environmental Humanities Laboratory, KTH, Stockholm, Sweden
} 
of their labour, denial of opportunities for future generations, oppression of minorities, toxicity and socially constructed diseases, to mention a few)? There is no simple answer to this question. Perhaps, Gramsci can help us to understand the intricacies and even contradictions of capitalist success through the concept of hegemony (Ramos, 1982). Capitalist elites exercise their power through coercion, violence, and expropriation, but also by "winning over" subaltern classes, imposing on them a hegemonic discourse that reproduces subalternity while convincing subalterns that they can change their conditions through "hard work" and competition. Discourses have always been a key tool in normalizing injustice and inequality. In fact, the origins of capitalism are closely linked to the spread of discourses of racial superiority and even dehumanization of Indigenous peoples in the colonies and women everywhere (Federici, 2004). As the consolidation of patriarchal and colonial structures have proved in the subsequent centuries, discourse formation is closely interlinked with material conditions of life.

The use of discourse is not only something from the past. In the current neoliberal era of capitalism, elites are crafting intricate narratives to legitimize austerity, precarity, environmental degradation and coloniality among other things. Naomi Klein, for example, describes how advocates of neoliberalism portray devastating catastrophes, such as natural disasters or terrorist attacks, as opportunities to implement freemarket policies in what she describes as a 'shock doctrine' (2007). This requires the creation of a dehumanizing discourse in which disasters are assessed quantitatively and even the loss of human lives is evaluated in economic terms. Economistic assessments of disasters are then used to justify private investment, which is presented as the only possible way to revitalize the battered local economy. It is precisely this widespread perception of capitalism as the only possible system that Mark Fisher calls 'capitalist realism' (2009). Borrowing a quote originally attributed to Jameson and Žižek, Fisher asserts that "it is easier to imagine the end of the world than the end of capitalism" (Ibid., p. 2). He goes on to unpack this idea by describing how cultural agencies, including the media and the educational system, work in ways that preclude the possibility of even imagining alternatives. An important parcel of this strategy relies on the systematic erasure of non-mainstream (hi)stories of 
resistance and lived alternatives; another world is not only impossible in the present, it must disappear from our stories about the past and from our imagination of the future. It might be worth mentioning here, as example, the recent decision in the UK by the Department of Education to forbid the use in schools of any material produced by anti-capitalist groups (Busby, 2020). The concept of 'capitalist realism' highlights the tight connection between discourses and material conditions of life, as the narratives that narrow the realm of possibility also constrain transformative thought and action (Fisher, 2009, p. 16). Rancière examines closer the mechanisms of legitimization of inequality and injustice in the creation of what he calls the 'distribution of the sensible': the perception and normalization of what constitutes common sense, and what is excluded from it (2004/2013). In fact, Rancière claims that history is a form of fiction: "Politics and art, like forms of knowledge, construct 'fictions', that is to say material rearrangements of signs and images, relationships between what is seen and what is said, between what is done and what can be done" (Ibid., p. 39). Therefore, Rancière expands the analysis to aesthetic forms beyond the narrative in analysing discourse formation, and the way it shapes our perception of the world and the realm of political possibility. In political ecology, Stefania Barca (2014) and Armiero et al. (2019) have both argued that the imposition of environmental injustice always comes hand-in-hand with the imposition of a toxic narrative, ${ }^{1}$ which either silences or normalizes injustice. This means that the struggles for environmental justice are always also struggles for narrative justice.

Although sophisticated, the capitalist systems of normalization described above do not go uncontested. The totalizing and homogenizing forces of capital cannot stop the constant emergence of cracks that, although usually not deep enough to threaten the system, constitute alternatives to a few people and prefigure ways of inhabiting the world that do not abide to capital (Holloway, 2010). A form of resistance that has been repeatedly used across multiple geographies and historical moments is that of commoning. Colonized indigenous peoples,

\footnotetext{
${ }^{1}$ Toxic narratives are those rhetoric dispositifs that silence, invisibilize or normalize injustices, often resulting in blaming the victims for their conditions (Armiero et al., 2019).
} 
exploited factory workers, peasants in the global South, urban dwellers fighting for the right to the city, women fighting against patriarchy, in all these examples and beyond, commoning has been experienced as a radical alternative to the totalitarianism of capitalist realism that imposes individualism and private property.

We frame commoning as the socio-ecological infrastructure that (re)produces commons through care, sharing, and inclusion, therefore sabotaging the wasting relationships that produce inequalities through extraction, privatization and exclusion (Armiero, 2021). Through commoning, commoners do not only share and have access to a set of resources, they are also entitled to decide on the ways of using and sharing them, while enhancing relationships of cooperation and mutuality among them and with the environment. In this sense, we argue that commoning has the emancipatory potential to advance socioecological relationships based on cooperation, horizontality, openness and care. The beauty of commoning resides in that it is not only a form of resistance, but it performs an alternative: while capitalism sees commons as a thing to be expropriated and monetized, commoners practice commoning as a set of socio-ecological relationships that reproduce both commons and commoners. As De Angelis (2017) reminds us, only the commoning of socially reproductive activities (such as food growing, care work or energy provision) can bring about truly emancipatory commons that pose a viable alternative to capital. While capitalism frames social reproduction as a set of processes that reproduce labour power, emancipatory commoning puts the reproduction and wellbeing of the commoners at the very centre. Mainstream discourses and toxic narratives have worked hard to conceal these practices from the public eye. As Marina Sitrin and Darío Azzellini put it: "[o]fficial history ... is told by the "victors" and " $[t]$ hey have no interest in telling the history of people taking their lives into their own hands" (2014, p. 8).

In this chapter we aim to expand what we have called "guerrilla narrative" (Armiero et al., 2019), proposing it as a powerful tool for subaltern communities to resist marginalization and oppression. Our aim is to explore the possibilities of "guerrilla narrative" to uncover stories of commoning that challenge homogenizing discourses, toxic narratives and capitalist legitimacy. We want to explore the power of narrative strategies 
to expand the commons by advancing the production of commoning subjectivities. By counter-narratives we mean discursive and material strategies that re-invent the possibilities of the present while practising antagonist collective identities.

Section 3.2 deals with our positionality as militant researchers, our methodological choices, and the rationale for using Cooperation Birmingham as a case study. In Sect. 3.3, we go deeper into the concept of "guerrilla narrative", focusing on the possibilities that it offers in a context of commoning. In Sect. 3.4 we introduce the case study. First, we characterize the permanent crisis of social reproduction that is taking place in Birmingham. We then describe the foundation and basic dynamics of Cooperation Birmingham, a mutual aid organization in which commoning practices thrive. In Sect. 3.5 we examine in-depth the narratives and the co-production process of the Cooperation Birmingham newsletter, which we analyse within the guerrilla narrative framework. In Sect. 3.6 we broaden the scope of guerrilla narrative by examining how the cooking and caring at the solidarity kitchen were central in creating commoning subjectivities. We argue that these very material practices hold an inherent narrative power, and that literary forms of guerrilla narrative are enhanced by them.

\section{Democratizing Knowledge Through Militant Research}

To better grasp the scope of this chapter, it is crucial to understand our positionality. We both take seriously the need for transformative change, and are active members of several political and environmental groups. We consciously engage in commoning practices in our everyday lives and in our academic work. We recognize that knowledge and power are closely linked while denying claims of neutrality and objectivity in our own research. Instead, following the tradition of militant and other action oriented approaches to research, we take sides and produce knowledge that aims to advance specific struggles (Derickson \& Routledge, 2015; Halvorsen, 2015). We recognize academia as a site of political struggle, where knowledge production can be directed either to reinforce the status 
quo, often under the pretence of scientific neutrality, or to achieve social transformations. Thereby, in producing politically loaded research, we maintain our scholarly integrity, we do not falsificate our sources, we do not conceal information for the sake of our argument, while engaging in "research that produces knowledge for social struggle and is itself a form of political intervention” (Dalton \& Mason-Deese, 2012, p. 445). Following Sandra Harding's "strong objectivity" approach (1995), we maintain that producing situated knowledge does not jeopardize but rather enhances the quality of that knowledge. It is this approach that informs our intentions with this chapter. We aim to advance knowledge on guerrilla narrative and its potential to contribute to the expansion of the commons, both theoretically and in practice.

Armiero et al. (2019) have defined guerrilla narrative as the sabotage of toxic narratives, or, in other words, the occupation of that space with counter-hegemonic storytelling. They have employed guerrilla narrative mainly as a tool to uncover the toxic legacy of capitalism in the lives of subalterns. With this chapter we aim to mobilize guerrilla narrative as a creative path to nurture alternatives to capitalist realism, especially in the forms of commoning. This chapter is grounded on real life struggles. Our insights and reflections are aimed at supporting the mutual aid efforts of Cooperation Birmingham, an organization based in the city of Birmingham, United Kingdom. The first author of this chapter is an active member in several political organizations and community groups in the West Midlands of England (the region where Birmingham is located), and is one of the co-founders of Cooperation Birmingham. We hope that our insights will help advance the goals of the organization.

Cooperation Birmingham is a mutual aid organization established in March 2020 that has been active in providing relief to people living in poverty and self-isolating during the Covid-19 pandemic. However, members of the organization see the recent sanitary crisis as the tip of an iceberg that has been forming during the last decades with the dismantling of the welfare state and the harshening of the living conditions of the subalterns in the UK. Therefore, the long-term goal of the project is to bring together several local organizations (both formal and informal) in order to provide a social and material infrastructure for 
enhancing the empowerment and autonomy of marginalized communities (Ruiz Cayuela, 2020a). At the same time, Cooperation Birmingham works on spreading a culture of self-organization and solidarity in the city, as viable alternatives to capital and the state. Even if the concept of "guerrilla narrative" is not explicitly used by members of Cooperation Birmingham, the values represented in the organization, the fact that it emerges from the community, and the importance given to diverse narrative practices that emerge from below, make it a suitable case study for this chapter.

Data collection for this chapter is closely linked to the material coproduced by Cooperation Birmingham. Our main source is the four issues of the newsletter that the organization published between May and August $2020 .^{2}$ The newsletter was widely distributed through different channels. Printed copies were delivered with meals, made available for free at the local Warehouse Cafe, and given to participants of Cooperation Birmingham to share with whom they wished. The newsletter was also distributed online through Cooperation Birmingham's blog and social media, both as a pdf and as a podcast. It has become an open space for people to express their feelings and ideas. In order to complement and contextualize the newsletters, we use other material posted on social media and on the Cooperation Birmingham website; we also use minutes from the meetings of the organization, which are accessible to the public in an open online forum. ${ }^{3}$ Finally, we also rely on field notes and personal experiences from the first author, who has been actively involved in the project. This connects our work with militant ethnographic scholarship and practice, which favours a qualitative approach in which the experience of the researcher is emphasized (Juris, 2007). It is important to stress that we have chosen to place the co-produced newsletters and other narrative practices at the core of the discussion and theoretical development. By doing this, and in line with the recent scholarship in "guerrilla narrative", we aim to democratize knowledge production, legitimize different formats as valid sources of knowledge,

\footnotetext{
2 You can access all the newsletters through Cooperation Birmingham's blog: https://cooperati onbirmingham.org.uk/blog/

3 https://forum.cooperationbirmingham.org.uk/.
} 
and to implicitly acknowledge all the contributors as co-producers of this chapter.

\section{Guerrilla Narrative}

We started to speak about guerrilla narrative in 2017, when a modest grant allowed the Environmental Humanities Laboratory ${ }^{4}$ to launch the ToxicBios project. The aim was to gather stories of contamination as experienced and narrated by affected individuals and communities and make them available in an online, open access archive. Our inspiration was the massive EJAtlas, ${ }^{5}$ coordinated by Joan Martinez Alier, the largest open access worldwide database on environmental conflicts. The idea was to explore environmental justice controversies from a humanities perspective, building on the assumption that every environmental justice struggle is also a struggle over narratives. Stefania Barca (2014) has spoken of narrative injustice, silencing crucial information and suppressing stories that do not fit into the mainstream celebration of economic growth. Armiero et al. (2019) have built their guerrilla narrative proposal in opposition to what they call "toxic narratives", that is, the rhetoric device operationalized to blame the victims for any kind of problems they are experiencing while naturalizing socio-ecological injustices. Guerrilla narrative works within and against the toxic narratives; while the latter constitute the narrative infrastructure supporting othering and oppression, the former sabotages that infrastructure fostering alternative memories and counter-hegemonic ways of reproducing them.

Toxic narratives are especially instrumental in maintaining the status quo when large environmental disasters expose the socio-environmental injustices that are underneath those exceptional events. In those cases, the toxic narrative infrastructure provides explanations of the disaster that never question its causes while promoting an anesthetized memory of it, purified from anger and outrage. Think for instance of the Vajont Dam

\footnotetext{
${ }^{4}$ The Environmental Humanities Laboratory is based at the KTH Royal Institute of Technology (Stockholm, Sweden) working at the intersection of environmental humanities and political ecology.

${ }^{5}$ https://ejatlas.org/.
} 
Disaster that in 1963 killed almost 2,000 people in the Italian Northeast. There, the toxic narrative implied the naturalization of the event, with both scientific experts and journalists explaining it as a natural disaster, blaming the geology of the mountains rather than the negligence of the corporation or the state. Exemplary of this naturalization is what Dino Buzzati, an influential writer and journalist, wrote immediately after the disaster:

A stone falls into a glass of water and the water is spilled on the tablecloth. That's it. But that the glass was hundreds of metres high and the stone was as big as a mountain; and below, on the tablecloth, there were thousands of human beings who could not defend themselves. It is not that the glass was intrinsically broken: therefore, we cannot call monsters those who built it, as in the case of the Gleno disaster. The glass was built perfectly ... Once again the fantasy of nature has been bigger and smarter than the fantasy of science. Although defeated in open battle, nature takes its revenge from behind. ${ }^{6}$

Evidently, the attempt to naturalize the event was key, not only for producing a pacified memory but also as a strategy to absolve the corporation and the public officials from their responsibilities. As any efficient toxic narrative, the one about the Vajont also led to the erasure of that story from the collective memory of the nation, and the imposition of a defused local memory where pain and mourning should be performed in tidy and pacified manners. The clash between a guerrilla narrative approach and the mainstream toxic narrative became clear in the story of the two Vajont cemeteries, brightly narrated by the Italian writer Lucia Vastano (2008). In 2000, the original cemetery, built by the survivors after the disaster and inhabited by personal memories and rage, was razed to the ground and replaced with a new cemetery, built by the authorities following the scheme of the war memorials, therefore, completely anonymized and pacified.

Or we can mention the parents who have lost their children due to rare oncological illnesses in the Neapolitan region and have been accused of

\footnotetext{
${ }^{6}$ Dino Buzzati, 'Natura crudele', Il Corriere della Sera, 11 October 1963, quoted here from Armiero (2011).
} 
transforming a private suffering into a public fact. In this case, guerrilla narrative implied to counter-act against the toxic mainstream interpretations of the health crisis occurring in the region; this either blamed the victims (if they got sick, it was because of their lifestyle) or denied the very crisis ("there is no evidence of a correlation between contamination and health problems"). The visual project "Postcards from the Land of Fires", realized by the photographer Mauro Pagnano, was an example of guerrilla narrative, a way of telling the story of suffering and contamination from an embodied point of view. ${ }^{7}$ The project gathered a collection of photographs depicting mothers in the rooms that were once occupied by their deceased children, each of them holding in her hands a photograph of the child. According to several commentators, this project was inappropriate because suffering should remain a private issue not something to use in the public sphere. Again, we see toxic narratives silencing injustices and defusing rage, versus guerrilla narrative, reclaiming the right to remember and to tell the stories of oppression and violence.

As these two examples help to clarify, we envision guerrilla narrative as the ensemble of practices that resist toxic narratives while proposing alternative (hi)stories and identities. In this sense guerrilla narrative is not simply the unheard story of oppression reclaimed from the memory dump; rather, guerrilla narrative is the practice of reimagining subaltern stories, storying them, and making collective identities. If it is true that the first step to crush a community is to take its history away (Klein et al., 2009), regaining control of the ways of remembering and storytelling is first and foremost an act of sabotage. This is what we can learn from Indigenous people who have been fighting against the erasure of their stories and memories for centuries, to the point of materially disappearing from the face of the earth; it is telling that the Zapatistas' covering of their faces was explained as a way of making visible those who had been invisibilized by centuries of colonial oppression (Khasnabish, 2013, pp. 12-13).

The toxic narrative infrastructure does not only conceal socioecological injustices, it prevents even the possibility of seeing them and imagining another world. This is why we decided to speak of guerrilla

\footnotetext{
7 https://mauropagnanophotographer.viewbook.com/homepage/album/terra-dei-fuochi.
} 
narrative and not simply of oral history, although oral history is an important root of guerrilla narrative. Guerrilla narrative implies recognizing that a counter-hegemonic storytelling does not occur in a political vacuum; rather, it strives to emerge under the harsh repression and authoritarianism of mainstream narratives. Given the disparities of the conflicting forces and the violence of toxic narratives, guerrilla narrative is the only realistic choice available to enhance counter-hegemonic visions. As Vitaliano Ravagli and Wu Ming (2005, pp. 148-149) have written:

To understand something, you need to crumble the myth as it has been handed down to us and dig out from the ruins the living stories. Those that no one has told. The axes to dig up.

The idea that stories are axes to dig up, tools to sabotage the toxic narrative infrastructure that controls the systems of feeling and memories is at the core of the guerrilla narrative project.

Oral history has also aimed at recovering untold (hi)stories while including subjects who have been generally excluded into historical narratives. Guerrilla narrative is a close relative of oral history, but it has a clearer political stance and an antagonist character: subaltern stories do not add nuances to mainstream narratives, they dismantle them. Furthermore, guerrilla narrative recognizes the plurality of means beyond orality through which subaltern people build counter-hegemonic storytelling, including arts, written documents, people's schools, or interventions into the mainstream organizations of public memories. Black Lives Matter, for instance, has questioned racist and colonial monuments and other toxic narratives inscribed into the texture of our collective lives (Lai, 2020).

We envision guerrilla narrative more as a DIY practice than a method. The guerrilla narrative bricolage nature refers to both the radical rejection of the researcher/researched dichotomy and to the creative mobilization of what is already available. While challenging the professionalization of knowledge production, guerrilla narrative humbly acknowledges that counter-hegemonic storytelling has always occurred without any need to be codified by academics. 
The ToxicBios project provides the largest empirical experiment in guerrilla narrative, to date gathering about 70 autobiographies, mostly in video formats, but also texts, audios and other more artistic formats (including songs and poems). Although the project has an unquestionable anthropocentric focus and an inclination towards individual narratives, in its realization, that is, in the bricolage of counter-hegemonic storytelling, it often challenges these limits. Several storytellers have included in their autobiographical accounts of contamination of nonhuman companions, such as for instance fish, ${ }^{8}$ trees $^{9}$ or a river. ${ }^{10}$ The tension between individual and collective stories almost explodes in the choral narration of Enzo's biography, which as the title clearly states, he would have never told himself. ${ }^{11}$ Instead, six friends, all militants in the same grassroots organization, decided to narrate Enzo's story, therefore, pushing back against the borders that police individual and collective identities. Similarly, in the ToxicBios project there were other collective stories, told by groups of people rather than individuals.

We envision guerrilla narrative not as a methodology, but a DIY assemblage of existing practices that have been employed broadly beyond the use of that specific label. We have mentioned, for instance, Black Lives Matter's challenge of racist and colonial monuments and the Zapatistas fight against invisibilization, but we could also include a $N o$ una de menos attack on the codified symbols of patriarchy, being them a statue, the usual all-male syllabus, or the functioning of our languages. ${ }^{12}$ Environmental justice movements have often cultivated some forms of counter-hegemonic narratives, preserving their histories and building

\footnotetext{
${ }^{8}$ Arlindo Marques and the Tejo river pollution, available at http://www.toxicbios.eu/\#/stories.

${ }^{9}$ Angela Rosa, fighting oil and natural gas exploration, available at http://www.toxicbios.eu/\#/ stories.

${ }^{10}$ António Pinto and Rosa Maria Pratas from ADACE in Aveiro, available at http://www.tox icbios.eu/\#/stories.

${ }^{11}$ Enzo Tosti would never tell his story, available at http://www.toxicbios.eu/\#/stories.

12 In order to give a few concrete examples of this, we can mention the repeated attack against the statue of a famous Italian journalist, Indro Montanelli, accused of raping an African teenager during the colonial war in Ethiopia. The number of initiatives sanctioning all-male syllabi in university courses has skyrocketed and it would be imposisble to list all of them. Similarly, the struggles for more inclusive languages have become crucial both in social movements and in academia.
} 
positive identities. This is the case, for instance, of the movement generated around the ex-SNIA Viscosa factory in Rome, Italy, especially in its effort to recover the (hi)stories of resistance against the toxic regime of the factory through the recovery of workers' files, abandoned in the building, and the creation of a self-managed archive (Tola, 2019).

Narrowing down to academic and research practices, we can mention the collective Guerrilla Cartography, for instance, that seems to be inspired by a similar counter-hegemonic approach in their production, together with communities, of thematic atlases. ${ }^{13}$ Directly inspired by Toxic Bios is the Guerrilla Digital Public History seminar created by Shawn Graham at Carleton University in Ottawa, Canada, which asks the crucial question: "What are the stories in Ottawa that require a guerrilla digital public history?" 14 In Tuzla, Bosnia Herzegovina, a group of researchers has joined forces with workers creating the Workers' University; this has produced narratives, even a graphic novel, on the present and past struggles in the city's chemical factory. ${ }^{15}$

All these examples demonstrate that, as we have argued above, guerrilla narrative is both the very stories produced through it and the process of producing/looking for them. Just as commons cannot be decoupled from commoning, that is from the socio-ecological practices (re)producing commons, in the same way, counter-hegemonic stories are not independent from guerrilla narrative, that is, from the narrative practices (re)producing those stories. Guerrilla narrative and commoning are bound together as performative practices that produce very material outputs (counter-hegemonic stories and commons) as well as socio-ecological subjectivities. In other words, guerrilla narrative or commoning are not "natural" products of a specific kind of community, rather in practising them new communities are co-produced.

\footnotetext{
13 https://www.guerrillacartography.org/.

14 https://shawngraham.github.io/guerrilla-dh/\#.

15 https://reclaimingdita.com/thestory.
} 


\section{From crises of Social Reproduction to Commoning and Mutual Aid}

Birmingham is the second most populated city in the UK within municipal boundaries, with over 1 million inhabitants. It is a very ethnically diverse, working-class city with a strong presence of migrant communities. Birmingham has been in an almost permanent crisis for years, and a significant proportion of its population live in poverty. A report released in June 2020 reveals that by that time, Birmingham had a 14.5\% rate of claimant unemployment, compared to a $7.8 \%$ for the whole country (Birmingham City Council, 2020). Another report published by the Office for National Statistics in 2018 indicated that Birmingham was one of the cities with most non-permanent workers in the UK, with around $8 \%$ of the active population working 'zero-hours' contracts, seasonal or casual contracts (Gouk \& Rodger, 2018). These and other dire economic statistics reflect the dramatic conditions in which people in Birmingham are forced to live. However, it is by looking at the 'nonproductive' activities and relationships that we can better understand the context. Birmingham hosts the two districts that top the national ranking of child poverty. In fact, one third of the children in the city live in poverty (Francis-Devine, 2020). Many people struggle to cover even their basic needs, including food. In 2017, for example, 33,500 people in Birmingham used food banks (Belcher, 2018), and the number has kept rising in recent years. Housing and hunger crises have become the norm for a considerable number of Brummies, and the situation is currently being further aggravated by the Covid-19 pandemic (Lawrence, 2020).

However, as Massimo de Angelis (2007) puts it, these are just 'horror statistics' to which we have grown accustomed. The truth is that behind the cold numbers, there are people suffering and struggling. The most obvious group are workers who have been made redundant, those who have been forcibly turned non-permanent, and even those who still keep their jobs but who are constantly burdened with still more tasks and feel that they could be the next to be fired. Families living in poverty, and especially children, have also been enduring a stressing time due to the controversial withdrawal (and almost immediate restoration) of subsidized school-meals during mid-term 2020 (Brewer, 2020). 
And we should not overlook the devastating effects on mental health of economic hardship combined with a culture of individual responsibility and shaming of failure. In times of crisis, this has usually led to dramatic increases in the depression and even suicide rates (Zapata Hidalgo, 2020). This multidimensional and holistic understanding of the context leads us to an interpretation of crises as more than just falling rates of profit. Subalterns experience crises in very material ways, as a retrenchment of their level of well-being and even as a struggle to stay alive. The other side of an economic crisis, thus, is a multiplicity of 'crises of social reproduction' (Caffentzis, 1999). In fact, it is this dual character that makes crises disciplinary tools instrumental for the normal functioning of globalized capitalist markets (De Angelis, 2007). Therefore, what is at risk is not the reproduction of capital, but the reproduction of life. The crises of social reproduction skyrocketed when austerity policies were implemented after the 2008 economic crisis. Between 2010 and 2019, for example, the British government "announced more than 30 billion pounds ... in cuts to welfare payments, housing subsidies and social services" (Mueller, 2019), a further dismantling of the already diminished welfare state at the expense of the most marginalized. This trend of rampant neoliberalization can be traced back several decades and allows us to find the narrative foundations that normalize the extreme situation lived by the subalterns in the UK today: contempt for 'the other', fierce competition, and extreme individualism. This is the toxic legacy of Thatcher's foundational credo: "there is no such thing as society, there are individual men and women".

Cooperation Birmingham is an initiative ignited by a group of people involved in political organizations, community groups and workers' and housing cooperatives. Inspired by Cooperation Jackson ${ }^{16}$ in the US and their quest for economic democracy (Akuno \& Nangwaya, 2017), Cooperation Birmingham aims to become an active partnership between formal organizations committed to social transformation (e.g., cooperatives or unions) and politicized grassroots organizations. The idea is that the former can materially and logistically support the latter, thus

\footnotetext{
${ }^{16}$ In fact, when Kali Akuno (spokesperson of Cooperation Jackson) visited Birmingham in May 2019, he was invited and hosted by several members of what would become Cooperation Birmingham.
} 
enabling an expansion of autonomous commoning practices in the city. The organization was supposed to start building a base of support, developing a participatory model, and gradually becoming active through 2020. However, when Covid-19 struck and deepened the manifold crises of social reproduction described above, members of Cooperation Birmingham felt the urge to provide crisis relief and stepped forward. In March 2020, Cooperation Birmingham started running a solidarity kitchen, a self-organized effort to deliver a daily healthy and hearty warm meal to people in need and/or self-isolation (Ruiz Cayuela, 2020b). Between March and August they delivered over 20,000 meals relying entirely on donations, infrastructural support from local co-ops, and the voluntary work of over 200 participants. The solidarity kitchen was framed as a mutual aid project. Decision-making was made in open online assemblies that all participants were encouraged to attend. An open online forum was enabled where all the minutes were made public and everyone could add items to the meetings' agendas or raise discussions. The kitchen crew and drivers were always given a meal in exchange for their work.

In addition to the solidarity kitchen, Cooperation Birmingham also produced and distributed reusable protective face masks used during the pandemic. It is also interesting to see how the solidarity kitchen has had spin-offs with a more sustainable scope, such as a food delivery workers' cooperative that is already running, and a compost production project that is still under discussion.

The values enacted and the strategies developed during this time make Cooperation Birmingham a clear example of commoning. In fact, members of Cooperation Birmingham have been inspired by commoning theories and experiences when planning a strategy of consolidation and expansion of the organization. On the one hand, this strategy aimed to expand the material autonomy and social reproduction capacity of Cooperation Birmingham; on the other hand, it intended to produce new commoning subjectivities within and beyond the borders of the organization (Ruiz Cayuela, 2021). In the next section, we will use a guerrilla narrative lens to investigate the narrative strategies used by Cooperation Birmingham that contributed to the creation of commoning subjectivities. Broadly speaking, the organization was 
consciously focused on dismantling the idea of charity, which is hegemonic in the UK third sector, and replacing it with discourses and practices of solidarity and mutual aid. Various forms of communication were used to convey this message, including direct conversation with occasional participants and food recipients, posts on social media, open online discussions on the forum, or website information and articles. However, the most focused and sustained effort to challenge toxic narratives and create anew was the co-production of a newsletter.

\section{The Cooperation Birmingham Newsletter}

The Cooperation Birmingham newsletter takes the form of an A3 sized triptych, with articles on one side and artwork on the other so it can be used as a poster. Around 300 physical copies of each issue were printed and distributed, but it was also posted online as a pdf and as a podcast. The newsletter was first edited in mid-May, less than two months after the solidarity kitchen started running. By that time, the solidarity kitchen was working smoothly and Cooperation Birmingham was gaining popularity. Although some of the inherent values were being practised on the ground (avoiding gatekeeping practices for example, "we ask no questions and we take no money"), the prioritization of the material emergency relief was somehow watering down the political nature of the organization. The general feeling in the group was that Cooperation Birmingham was successful in delivering meals, but not messages. Some members called this fact to attention, and proposed the creation of a newsletter. The newsletter was conceived as an open space where everyone related with Cooperation Birmingham or sister organizations could write about a variety of topics of interest. It was a co-produced effort where an open and horizontal organization was trying to show with practical examples that cooperation, solidarity and self-organization are all valuable practices for the subaltern communities.

One of the main goals of the Cooperation Birmingham newsletter has been to challenge and dismantle mainstream toxic narratives that seek to divide subaltern communities and pit them against each other. This was clearly stated in the very first issue, where individualism was 
tackled with a poster displaying the message "all we have is each other" (see Fig. 3.1), and an article by the same title proclaimed that "only in cooperation (and not in competition, like we have been told) we thrive". In that same issue, narratives that criminalize the poor and hold them accountable for their situation were addressed with an article about rent strikes. In it, the anonymous author went on, affirming that "housing IS healthcare" [original emphasis] and that "[e]victions in the middle of a pandemic are a health hazard", to finalize the article with stories of successful rent strikes happening at the time. In the second issue, a guest article by a member of the sister organization Cooperation Town (from Kentish Town, London) contested the framing of the pandemic as a natural disaster by highlighting the already existing crises of social reproduction that many communities were facing before the pandemic, and the dismantling of public services that has taken place over the last decade. In that same issue, members of Cooperation Birmingham wrote a statement explaining their decision to refer to people involved in the project as 'participants' instead of 'volunteers'. They associated the term 'volunteer' with the practice of charity, and explained how it hides power relationships. Rejecting hierarchical structures within organizations and between 'volunteers' and recipients, the authors wrote: "we do not work for anyone but for the people involved... We are all participants and we can all participate!".

The third and fourth issues, launched in June and July 2020 during the peak of the Black Lives Matter movement worldwide and in the UK, were especially vocal against racism. Right after the murder of George Floyd, ${ }^{17}$ Cooperation Birmingham encouraged people to attend local anti-racist protests by acknowledging that "racial discrimination and oppression is also happening here in the UK, where it is linked to a colonialist past and present". In the fourth issue, an article titled Black Lives Matter celebrated the toppling of the statue of slave trader Edward Colston in Bristol, and responded to prime minister Boris Johnson's attempt to stop the widespread protests by stating that Britain is not a racist country. "This is a lie", the anonymous author wrote before

\footnotetext{
17 George Floyd was a black man who was murdered by a police officer on 25 May 2020 in Minneapolis. His death sparked a global upsurge of the Black Lives Matter movement that took the form of demonstrations and riots against racialized police brutality all around the world.
} 

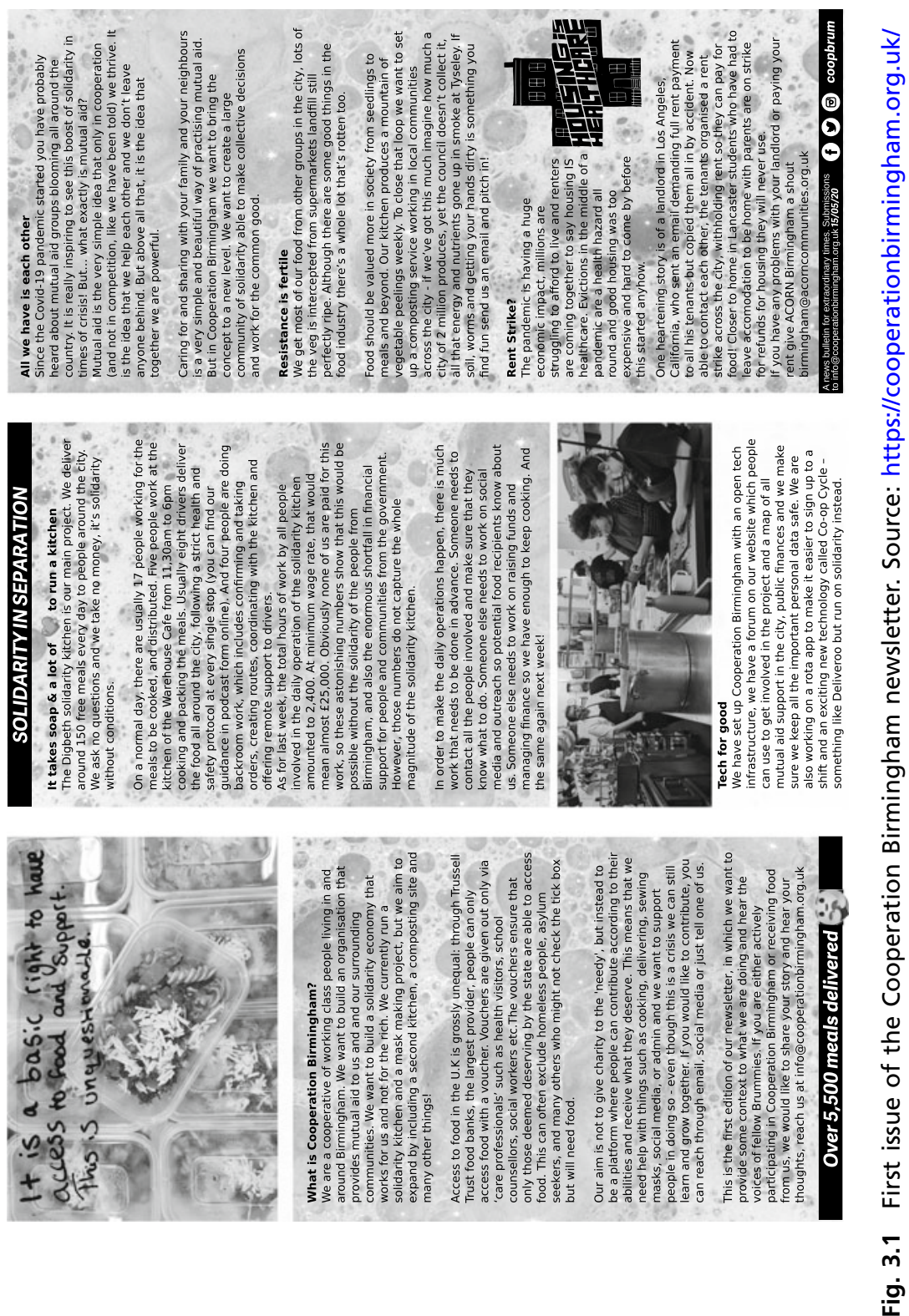
backing the defiance with telling numbers. These are just some examples that show how the newsletter was used by Cooperation Birmingham to directly confront narratives normalizing individualism, competition, the criminalization of poverty, classism and racism. The first step towards building commoning subjectivities is uncovering and unlearning deeply held toxic narratives that translate into isolation, division and discrimination; and therefore threaten the emancipatory character of commoning practices.

However, Cooperation Birmingham's newsletter was not limited to the denunciation of mainstream narratives and their noxious effects. The construction of alternative narratives was at least as important. In fact, the sabotaging of a toxic narrative and the building of alternatives happen simultaneously and are inherently connected. Let us emphasize, 'alternative narratives', in plural, because against the imposition of a single homogenizing story, members of Cooperation Birmingham consciously sought to include a diverse array of perspectives in their newsletter. The first issue of the newsletter included a brief description of the organization that described Cooperation Birmingham as a mutual aid network. In the same issue, an anonymous author sought to explain the idea of mutual aid in simple terms, and finished by stating: "We want to create a large community of solidarity able to make collective decisions and work for the common good". The second issue gave concrete shape to those ideas through the contributions of two members of Cooperation Birmingham. Bea Hughes, a kitchen participant, described her experience as enjoyable and empowering. Her relaxed tone helped to tear down the psychological barrier between 'the masses' and 'the vanguard', making of 'joyful militancy' an easily relatable feeling. Shamima Akhtar, a food recipient, reported the huge value that solidarity and care have for the subalterns' bodies and minds: "This is the type of unquestioned support 'vulnerable' people like me need, rather than charity-based support that puts pity at its centre". In that same issue, the newsletter pointed towards the formation of a political subject beyond the locality by including an article written by a member of London based Cooperation Town. Only by creating an autonomous wider network of solidarity "we can resist going back to the harmful 'normality' ... and plot our way towards a better future" they asserted. 
The third issue included an anonymous proposal for addressing food sovereignty issues within Cooperation Birmingham, and framed the creation of a decommodified food system as a way towards autonomy and socio-environmental justice: "If the people who grow, prepare, distribute and eat food can be freed from needing to spend and earn money, a fairer food and farming system is possible". Still reinforcing the idea of solidarity networks and the forging of political subjects on a wider scale, the third issue also included an article by a member of the local red gym, who called for more comradely and enjoyable collective spaces where people from all genders and ethnicities can feel comfortable to exercise their bodies. In the same number, one of the chefs of the solidarity kitchen told the epic story of how the radically democratic structure of the anti-imperialist movement in Poland allowed him to get highly valuable cheffing skills. In the fourth issue, the article 'Common People' called for "reclaim[ing] a new commons as a way to provide for ourselves". The anonymous author pointed towards three main pillars that should inform all commoning practices, and thus all the activities of Cooperation Birmingham: solidarity, self-organization and direct democracy.

All these examples show how the Cooperation Birmingham newsletter has been building autonomous narratives that portray 'joyful militancy' within solidarity networks not only as a real possibility, but as materially desirable for people in need. Grounded on direct relatable examples, Cooperation Birmingham has been trying to build new subjectivities based on cooperation, autonomy, diversity, mutual aid, radical democracy and self-organization. In other words, the newsletter has aimed to build a political subject ready to reclaim and inhabit the emancipatory commons.

We argue that the diverse practices of co-production that were (and are still being) distilled into the Cooperation Birmingham newsletter constitute a form of storytelling that can be framed within the guerrilla narrative strategy. As we have seen, the articles and artwork included in the newsletter specifically tackle mainstream toxic narratives, taking them out of their apolitical vacuum, and dismantling them through first-hand experiences, practices and knowledge. At the same time, those articles are drawing from the concrete experiences of Cooperation Birmingham, 
its members, and sister organizations to build a diversity of autonomous narratives through which the subaltern can reclaim agency and lead the expansion of the commons.

Another feature that highlights the guerrilla character of the Cooperation Birmingham newsletter is the focus on the process. For it is not only the final publication, but the different steps in the co-production process, including the articulation of ideas and the challenging of preestablished roles, that produces commoning subjectivities. Participants of Cooperation Birmingham did not have previous experience in editing or publishing, so being able to create the newsletter felt like a huge success and reinforced comradeship and dignity among the people involved. These types of achievements constitute 'small victories' that can help to forge collective identities.

Written or recorded stories can be powerful tools for conveying ideas, values and even worldviews; the reader will surely relate to experiencing small (or big!) epiphanies while reading a book or listening to a song. In line with that, contributors to the newsletter are hopeful that the articles published and the pieces of artwork have helped to disseminate commoning values among the hundreds of people who received each issue on paper, and those who read or listened to them online. However, the collective process of exploration and co-production plays an even more important role in the course of building commoning subjectivities. Several contributors to the Cooperation Birmingham newsletter are people living in poverty, from diverse backgrounds and ethnicities. Most of them had been forced, through toxic narratives and disciplinary measures, to see themselves as passive recipients of information, to think that they did not have anything important to say. One of the biggest achievements of the newsletter has therefore been the sparking of a collective process of empowerment in which all, but especially contributors from marginalized backgrounds, have broken boundaries previously imposed by the hegemonic distribution of the sensible. They have rebelled against the unidirectionality and homogeneity of toxic narratives and have become active storytellers, builders of alternative identities and stories. This was especially visible to the editors, whose labour of guidance and support with highly insecure potential contributors was crucial to the co-production of the newsletter. In fact, not 
everyone who expressed willingness to participate in the project was able to overcome those barriers. Therefore, the very process of creating the Cooperation Birmingham newsletter had a deep effect in politicizing the people who contributed to its realization. The process of co-production of the newsletter did not only produce publications, but also a wider community of commoners, a group of particular socio-ecological subjectivities.

Finally, the production of the Cooperation Birmingham newsletter did not follow a structured and planned process that could be labelled as 'methodology'. It assembled a multiplicity of DIY existing narrative and artistic practices of different forms through a collective process that created a common ground while valuing their diversity. All these features not only frame the production of the Cooperation Birmingham newsletter as a guerrilla narrative practice, but provide a starting point for broadening the scope of the concept. This is a crucial step that can open new dimensions to be examined through the lens of guerrilla narrative. In fact, we have a direct example in the daily activities of the solidarity kitchen. Could we consider the work, care, affections and solidarity that took place among participants of Cooperation Birmingham embodied performances of guerrilla narrative?

\section{Embodying Guerrilla Narrative in the solidarity kitchen}

Silvia Federici and Nicole Cox have argued that traditionally the Left has been quite blind towards what occurs in the kitchen (and in the bedroom). Reproductive work and gender oppression have not received enough attention in the Left strategy for emancipation. As Federici and Cox write, "the struggle which the Left offers to the wageless, the "underdeveloped," is not a struggle against capital, but a struggle for capital, in a more rationalized, developed, and productive form" (1975/2012, pp. 29-30). However, the kitchen is not only a space of gender oppression and unpaid care work. In Re-enchanting the world, Silvia Federici (2018) reflects specifically on the collective kitchens organized by activist women engaged in various struggles. Federici mentions 
women's activities at the Standing Rock Camp, in North Dakota, which supported more than seven thousand people providing food, supplies and child care (Federici, 2018, p. 4). Quoting Raúl Zibechi, Federici reminds us of the 15,000 grassroots organizations that in the 1990s were providing food for children and neighbourhoods in Lima. As Federici argues, kitchens in social movements are relevant because they remind us of "the need for a politics that refuses to separate the time of political organizing from that of reproduction" (Ibid., p. 7).

One might say that the problem is not in working in the kitchen per se, rather in the kind of social relationships in which that work and space are embedded. Instead of the heart of the home or of a deeply gendered space, the common kitchen is a queer space where politics and aromas mixed with friendship and humour. Placing the kitchen at the centre of social mobilization implies a shift in the ways in which activists think of politics and engage with the communities around them. Caring becomes more relevant than leading, listening to the needs of people a more useful skill than mastering the arts of public speaking. Learning how to run a collective kitchen exercises the capacities to work together towards a common aim. A revolution built around the kitchen does not sever body and mind, collective dreams and individual needs, the discussion about the structures and the small gestures through which another world gleams in the capitalist desert.

We argue that, when analysing the production of the Cooperation Birmingham newsletter as a guerrilla narrative strategy, we should not sever the editorial activities from what happens in the kitchen. We have analysed the texts published in their newsletters but we should not forget that those A3 flyers were mostly delivered with a hot meal. Is it actually correct to disentangle those words from the tastes of the food, the comforting presence of someone bringing it to the front door, the laugh and the sweat shared in preparing it, the joy and the stress enacted? The centrality of the words, whether spoken in the assemblies or written in a flyer, poses a contradiction that risks leading us back to the same old politics, one where the kitchen is a private space, caring a gendered task and the revolution a business for disembodied militants. With their solidarity kitchen, Cooperation Birmingham has practised guerrilla narrative 
with vegetables, pasta and their own bodies; that kitchen has told thousands of people a story of solidarity and resistance, of empowerment beyond charity, of rage beyond frustration and individual failure. It has not been a kitchen created by commoners, but the other way around: the commoning practices that have taken place in the very acts of mutual aid have forged collective identities based on emancipatory value practices.

When we started to reflect about Cooperation Birmingham and their commoning experience, we almost immediately focused our attention on the newsletter. It was in the written texts that a counter-hegemonic narrative had to be found. Almost as an involuntary reflex, we were ready to reproduce the usual fracture dividing the guts and the politics, the kitchen and the assembly hall. We should not be too harsh with ourselves; after all, as we have reported above, the participants in Cooperation Birmingham also thought that the distribution of meals was taking over the political content of their work. This is why they started the newsletter- to convey their politics and to be explicit about their aims. However, at the end of our reflection, we ask ourselves whether it was actually the newsletter conveying Cooperation Birmingham politics or the food delivered with it. Ours is perhaps only a provocation; cooking and writing, delivering meals and managing a website were all part of the same commoning experience that sabotaged the toxic narratives of individualism and emergency while prefiguring another way of being together. Nonetheless, remarking that cooking together in a collective kitchen is an exercise of guerrilla narrative is crucial because, too easily, we tend to end up with a word-centred politics where the space of caring and commoning is reduced to a symbolic instance. Instead, with Silvia Federici we argue for the centrality of the "reproductive side of political work-the dinners together, the songs that strengthen our sense of being a collective subject, the affective relations we develop among each other" (Federici, 2020, p. 126). Cooking and writing, running a newsletter and a collective kitchen are two sides of the same commoning practice; we consider them as two languages that together deliver new counter-hegemonic narratives. In this case guerrilla narrative looks like a warm soup made of vegetables, stories and ties. And it tastes like a joyful revolution. 


\section{Conclusions}

In this chapter, we have addressed the need for strategies that challenge the sophisticated discourses used by elites to socially legitimize and normalize oppression and exploitation (to varying degrees) of a majority. We have briefly commented on the work of several authors who highlight diverse features of these totalizing devices that they characterize as 'shock doctrine', 'capitalism realism', 'distribution of the sensible' and 'toxic narratives'. However, they all reach a similar conclusion: narrative violence is being used to impose ways of living that lock-in and enhance privilege, inequality and environmental degradation. Based on our personal experience as militant researchers, and particularly our work on the Toxic Bios project, we have analysed the potential of the guerrilla narrative praxis to contest capitalism realism and create emancipatory alternatives. In particular, we have examined the narrative strategies used by Cooperation Birmingham that contribute to a material expansion of commoning, a set of relationships based on cooperation, solidarity, horizontality and care.

The case of the Cooperation Birmingham newsletter has contributed to the still scarce literature on guerrilla narrative by providing a detailed case study that confirms some of its defining traits. The articles published in the newsletter conform a diverse mix of topics and perspectives that challenge mainstream narratives associated with capitalist values while simultaneously normalizing commoning practices. However, confirming the process-oriented character of guerrilla narrative, we have found out that the published outcome is just the tip of the iceberg, and that all the invisible activities associated with the publication hold a great potential for building subjectivities based on cooperation and solidarity. In fact, the co-production process of the Cooperation Birmingham newsletter brought about the collective empowerment of many contributors, who were able to switch from passive objects to active subjects in history, subverting the dominant distribution of the sensible.

Following this line of analysis, in which we avoid reducing guerrilla narrative practices to mere outcomes, has allowed us to reach what is probably the main contribution of this article: the narrative power of material practices of care and solidarity. As we saw in the everyday 
activities of the Cooperation Birmingham solidarity kitchen, it is the labour, the interaction, and the multiple relationships forged among the participants of the kitchen that created the emergence of commoning subjectivities among them. Melissa García-Lamarca (2017) reached a similar conclusion when she examined the process of political subjectivation that took place at the Spanish anti-eviction popular movement (PAH). As she asserts, through experiencing "equal, non-commodified, and solidaristic relations" (429), a process of subjectivation took place that contested the common feeling of individual failure, and normalized collective and autonomous action when struggling against evictions. What these examples have in common is that material practices of social reproduction (like food or housing) are also narrative practices with the potential of subverting deeply embedded notions of capitalism realism and building commoning subjectivities. When we speak of guerrilla narrative, therefore, we need to start thinking beyond ink, paper, and even film reel. We need to mobilize expansive strategies that acknowledge and take advantage of the materiality of guerrilla narrative.

Acknowledgements This research received funding from the European Union's Horizon 2020 research and innovation programme under the Marie Sklowdoska-Curie Grant Agreement No. 765389.

\section{References}

Akuno, K., \& Nangwaya, A. (Eds.). (2017). Jackson rising: The struggle for economic democracy and black self-determination in Jackson. Daraja Press.

Armiero, M. (2011). A rugged nation. White Horse Press.

Armiero, M. (2021). Wasteocene. Stories from the global dump. Cambridge University Press.

Armiero, M., Andritsos, T., Barca, S., Brás, R., Ruiz Cauyela, S., Dedeoğlu, Ç., Di Pierri, M., Fernandes, L. D., Gravagno, F., Greco, L., \& Greyl, L. (2019). Toxic bios: Toxic autobiographies-A public environmental humanities project. Environmental Justice, 12(1), 7-11.

Barca, S. (2014). Telling the right story: Environmental violence and liberation narratives. Environment and History, 20(4), 535-546. 
Belcher, A. (2018, April 25). Foodbanks in Birmingham-Here's your nearest foodbank and how to access them. Birmingham Live. https://www.birmingha mmail.co.uk/news/midlands-news/foodbanks-birmingham-heres-your-nea rest-14500125

Birmingham City Council. (2020). Birmingham labour market update, Q2 2020. Inclusive Growth Directorate.

Brewer, F. (2020, October 30). The tories could feed poor children-They just don't want to. Novara Media. https://novaramedia.com/2020/10/30/the-tor ies-could-feed-poor-children-they-just-dont-want-to/

Busby, M. (2020, September 27). Schools in England told not to use material from anti-capitalist groups. The Guardian. https://www.theguardian.com/ education/2020/sep/27/uk-schools-told-not-to-use-anti-capitalist-materialin-teaching

Caffentzis, G. (1999). On the notion of a crisis of social reproduction: A theoretical review. In M. Dallacosta \& G. F. Dallacosta (Eds.), Women, development and labor of reproduction: Struggles and movements (pp. 153-187).

Dalton, C., \& Mason-Deese, L. (2012). Counter (Mapping) actions: Mapping as militant research. ACME: An International E-Journal for Critical Geographies, 11(3), 439-466.

De Angelis, M. (2007). The beginning of history: Value struggles and global capital. Pluto Press.

De Angelis, M. (2017). Omnia sunt communia: On the commons and the transformation to postcapitalism. Zed Books.

Derickson, K. D., \& Routledge, P. (2015). Resourcing scholar-activism: Collaboration, transformation, and the production of knowledge. The Professional Geographer, 67(1), 1-7.

Federici, S. (2004). Caliban and the witch. Autonomedia.

Federici, S. (2020). Beyond the periphery of the skin: Rethinking, remaking, and reclaiming the body in contemporary capitalism. PM Press.

Federici, S., \& Cox, N. (1975/2012). Counter-planning from the kitchen: wages for housework, a perspective on capital and the left. In S. Federici (Ed.), Revolution at point zero: Housework, reproduction and feminist struggle (pp. 28-40). PM Press.

Federici, S. (2018). Re-enchanting the world: Feminism and the politics of the commons. PM Press.

Fisher, M. (2009). Capitalist realism: Is there no alternative?. John Hunt Publishing.

Francis-Devine, B. (2020, April 29). Poverty in the UK: statistics. House of Commons Library Number 7096. House of Commons. 
García-Lamarca, M. (2017). Creating political subjects: Collective knowledge and action to enact housing rights in Spain. Community Development Journal, 52(3), 421-435.

Gouk, A., \& Rodger, J. (2018, May 10). Inside the Birmingham gig economy where shocking number of workers are on temporary contracts. Birmingham Live. https://www.birminghammail.co.uk/news/midlands-news/ins ide-birmingham-gig-economy-shocking-14642036

Halvorsen, S. (2015). Militant research against-and-beyond itself: Critical perspectives from the university and occupy London. Area, 47(4), 466-472. Harding, S. (1995). "Strong objectivity": A response to the new objectivity question. Synthese, 104(3), 331-349.

Holloway, J. (2010). Crack capitalism. Pluto Press.

Juris, J. (2007). Practicing militant ethnography. In D. David Graeber, S. Shukaitis, A. Negri \& E. Biddle (Eds.), Constituent imagination: Militant investigations, collective theorization (pp. 164-176). AK Press.

Khasnabish, A. (2013). Zapatistas: Rebellion from the grassroots to the global. Zed Books.

Klein, N. (2007). The shock doctrine: The rise of disaster capitalism. Macmillan.

Klein N., Whitecross, M., \& Winterbottom, M. (2009). The shock doctrine, documentary. Dogwoof.

Lai, T.-H. (2020). Political vandalism as counter-speech: A defense of defacing and destroying tainted monuments. European Journal of Philosophy, 28(3), 602-616.

Lawrence, F. (2020, April 11). UK hunger crisis: $1.5 \mathrm{~m}$ people go whole day without food. The Guardian. https://www.theguardian.com/society/2020/ apr/11/uk-hunger-crisis-15m-people-go-whole-day-without-food

Mueller, B. (2019, February 24). What is austerity and how has it affected British society? The New York Times. https:/www.nytimes.com/2019/02/24/ world/europe/britain-austerity-may-budget.html

Ramos, V. Jr. (1982). The concepts of ideology, hegemony, and organic intellectuals in Gramsci's Marxism. Theoretical Review, 27(3-8), 34. https://www. marxists.org/history/erol/periodicals/theoretical-review/1982301.htm

Rancière, J. (2004/2013). The politics of aesthetics. The distribution of the sensible. Bloomsbury Publishing.

Ravagli, V., \& Wu, M. (2005). Asce di guerra. Tropea.

Ruiz Cayuela, S. (2020a). An alternative economy for Birmingham. In Solidarity not charity: Mutual aid in Europe. Green European Journal, 20, 100 . 
Ruiz Cayuela, S. (2020b). Organising a solidarity kitchen: Reflections from Cooperation Birmingham. Interface: A journal for and about social movements, 21(1), 304-309.

Ruiz Cayuela, S. (2021). Bridging materiality and subjectivity: Expanding the commons in Cooperation Birmingham. Antipode, 53(5), 1546-1570.

Sitrin, M., \& Azzellini, D. (2014). They can't represent us!: Reinventing democracy from Greece to Occupy. Verso Books.

Tola, M. (2019). The archive and the lake: Labor, toxicity, and the making of cosmopolitical commons in Rome, Italy. Environmental Humanities, 11(1), $194-215$.

Vastano, L. (2008). Vajont, l'onda lunga: quarantacinque anni di truffe e soprusi contro chi sopravvisse alla notte piu crudele della Repubblica. Ponte alle Grazie. Wood, E. M. (1995). Democracy against capitalism: Renewing historical materialism. Cambridge University Press.

Zapata Hidalgo, M. (2020). Depressió i recuperació en mig de la voràgine. Catarsi Magazin, 3, 74-81.

Open Access This chapter is licensed under the terms of the Creative Commons Attribution 4.0 International License (http://creativecommons.org/ licenses/by/4.0/), which permits use, sharing, adaptation, distribution and reproduction in any medium or format, as long as you give appropriate credit to the original author(s) and the source, provide a link to the Creative Commons license and indicate if changes were made.

The images or other third party material in this chapter are included in the chapter's Creative Commons license, unless indicated otherwise in a credit line to the material. If material is not included in the chapter's Creative Commons license and your intended use is not permitted by statutory regulation or exceeds the permitted use, you will need to obtain permission directly from the copyright holder.

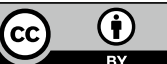

